\title{
Assessing Growth Performance of Tectona Grandis in Nepal
}

\author{
B.R. Pokhrel ${ }^{1}$, R.A. Mandal ${ }^{2 *}$ \\ ${ }^{1}$ Department of Forest and Soil Conservation \\ ${ }^{* 2}$ School of Environmental Science and Management
}

*Corresponding Author: Ram Asheshwar Mandal, PhD Scholar, School of Environmental Science and Management, Nepal, Email: ram.mandal@gmail.com

\begin{abstract}
The growth of any plant species is important characteristics which determine the yield of the plant. The growth performance of Tectona grandis was not so far assessed in Nepal. Therefore, this study was objectively carried out to assess the growth performance of T. grandis, show the relationship between the growth and soil nutrients and effect of spacing on the growth. Community and private plantations of this spp. in seven Tarai districts of Nepal were selected as study site. Altogether 215 samples were collected applying stratified random sampling. Particularly diameter and height of 8644 plants were measured and the spacing between plants was also recorded. The age of the plantation was noted from plantation report. Meanwhile, 102 soil samples were collected from 0-10, 10-20 and 20-30 cm depths. The increment of basal area, volume, biomass and carbon were analyzed and $N, P, K, C, p H$ and bulk density were evaluated in the lab. The result showed that mean annual stem volume was the higher $171.46 \mathrm{~m}^{3} / \mathrm{ha}$ in community plantation while it was only $92.61 \mathrm{~m}^{3} / \mathrm{ha}$ in private plantation. The average soil organic carbon in community plantation was estimated to be $38.29 \pm 6.05$ ton/ha whereas it was only $32.77 \pm 2.57$ ton/ha in private plantation. Total nitrogen was only $0.07 \%$ while $P$ and $K$ were 21.23 and $166.04 \mathrm{~kg} / \mathrm{ha}$ respectively in community plantation. Similarly, carbon and Nitrogen were $0.84 \%$ and $0.06 \%$ respectively in private plantation. The $P$ and $K$ were 53.29 and 171.55 $\mathrm{kg} / \mathrm{ha}$ simultaneously. The $\mathrm{pH}$ was 6.50 for community plantation and which was 6.46 in private plantation. The $R$ value of MABAI of T. grandis and carbon was low 0.49 but it was significant ( $p$ value $=0.00$ ). It was found that the highest MADI at $>3 \mathrm{~m}$ spacing with $1.33 \pm 0.028 \mathrm{~cm}$ but it was the lowest at $<2 \mathrm{~m}$ spacing with $1.17 \pm 0.018 \mathrm{~cm}$. This study will be useful to see the rotation and effect of spacing and soil fertility on growth performance.
\end{abstract}

Keywords: community, growth, plantation, private, spacing, Tectona grandis

\section{INTRODUCTION}

Globally the forest area covers 3,999 million ha (30.6\%) of land. About 299 million ha (7\%) of this is planted forest which had been increased by 105 million ha since 1990 (FAO, 2016). T. grandis plantation forest constitutes about 4.346 million ha and represents $75 \%$ of high tropical hardwood plantation, $83 \%$ of which is in tropical Asia (IUFRO, 2018). Teak (Tectona grandis L.F., is a member of Verbenaceae family, one of the most important, widely planted, a valuable hardwoods spp. (Robertson and Reilly, 2006). The success of large scale plantation is mainly due to its relatively fast growth, fire resistance, non-browsability, high survivable rate (Robertson and Reilly, 2006). Besides, it is termite resistance and widely used for boat and ship, building construction, decorative veneer, furniture, handicraft, musical instruments and has been recognized for centuries as a king among timbers due to its durability, workability, attractiveness and strength (KFRI and ITTO, 2003; FAO, 2016, Thapa and Gautam, 2007).

For most of the countries like Nepal, T. grandis is an introduced species (Jackson, 1994), stands for a good opportunity to produce quality timber and is a major asset for the forest economy. In Nepal, $T$. grandis plantation had begun from 1960 in Chiliya, Rupendehi (Kayastha, 1974) followed by some block plantation in Sagarnath, Sarlahi and Ratuwamai by Forest Product Development Board. There was a serious problem of great decline suffering from die back in Dalbergia sissoo reported so $T$. grandis plantation came as alternative of D. sissoo ( Paudel and Sah 2003).

T. grandis plantation has been prescribed for more than 60 years of rotation period for Nepal (Amatya and Shrestha, 2016). However, the growth performance is unknown. The growth is generally affected 
due to fertility of the soil (Silva and Uchida, 2000, Laar and Akca, 2007). In addition, the growth is also affected by spacing between plant to plant and row to row. So, such type of study was not so far done in Nepal. Therefore, this research was objectively carried out to assess annual increment of Tectona grandis at community and private plantation, find the status of soil nutrients and explore the effect of plantation spacing regime on growth

\section{Materials AND Methods}

\subsection{Study Site}

This study was conducted in community and private plantation of seven low land (Tarai) districts representative to whole $T$. grandis plantation area of Nepal. These included the whole plantation area from East, Central and West part of Nepal lying between $26^{\circ} 20^{\prime}-29^{\circ} 05^{\prime} \mathrm{N}$ latitude and $80^{\circ} 30^{\prime}-88^{\circ} 12^{\prime} \mathrm{E}$ longitude. The mean annual temperature is higher than $16^{\circ} \mathrm{C}$ and means annual rainfall is over $1500 \mathrm{~mm}$. These areas represent almost $15 \%$ of households and $15 \%$ of population of Nepal (CBS, 2011). About 583,940 ha of forest and other wooded land of Tarai area has been included in these districts (Figur1, Table1).

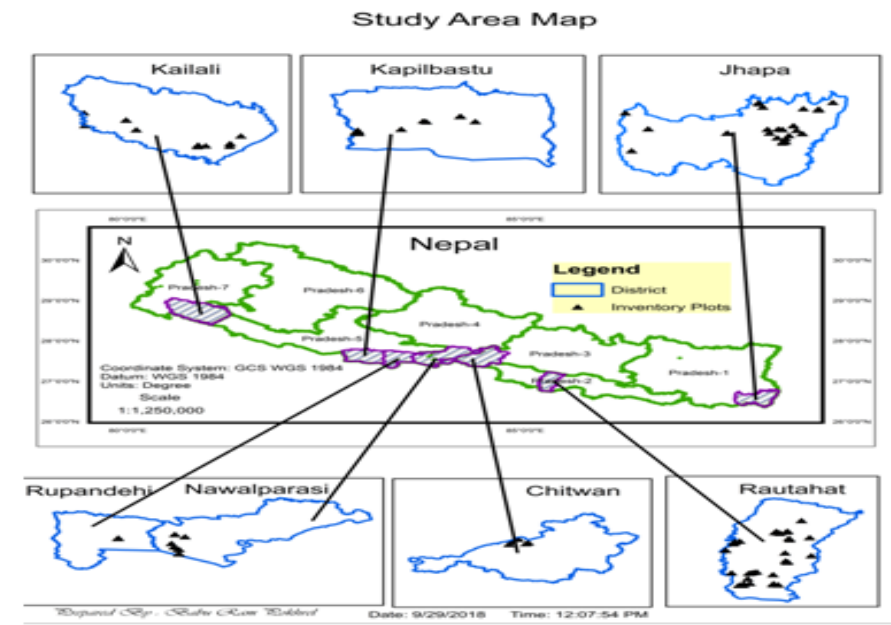

Figure1. Map of Study Area

Table1. Information about Study Area

\begin{tabular}{|c|c|c|c|c|c|c|c|c|}
\hline District & Latitude $\mathbf{N}$ & Longitude E & $\begin{array}{l}\text { Elevation } \\
\text { Range (m) }\end{array}$ & \begin{tabular}{|l|} 
Forest \\
area (ha)
\end{tabular} & \begin{tabular}{|l|} 
Other \\
wooded \\
land (ha)
\end{tabular} & \begin{tabular}{|l|} 
Total Area \\
(ha)
\end{tabular} & $\begin{array}{l}\text { Mean Annual } \\
\text { Temperature } \\
{ }^{0} \mathrm{C}\end{array}$ & $\begin{array}{l}\text { Annual } \\
\text { Rainfall } \\
(\mathbf{m m})\end{array}$ \\
\hline Jhapa & $26^{\circ} 20^{\prime}-26^{\circ} 50^{\prime}$ & $87^{\circ} 39^{\prime}-88^{\circ} 12^{\prime}$ & $58-500$ & 17,349 & 358 & 160,369 & 24.5 & $2,346.60$ \\
\hline Rautahat & $26^{\circ} 44^{\prime}-27^{\circ} 14^{\prime}$ & $85^{\circ} 14^{\prime}-85^{\circ} 30^{\prime}$ & $76-872$ & 25,874 & 414 & 103,816 & 16.1 & $1,537.80$ \\
\hline Chitwan & $27^{\circ} 22^{\prime}-27^{\circ} 53^{\prime}$ & $83^{\circ} 55^{\prime}-84^{\circ} 48^{\prime}$ & 244-1945 & 141,668 & 5,821 & 223,970 & 23.5 & $1,783.70$ \\
\hline Nawalparasi & $27^{\circ} 21^{\prime}-27^{\circ} 47^{\prime}$ & $83^{\circ} 36^{\prime}-84^{\circ} 35^{\prime}$ & 91-1936 & 103,593 & 1,813 & 215,255 & 23.6 & $1,952.80$ \\
\hline Rupandehi & $27^{\circ} 20^{\prime}-27^{\circ} 47^{\prime}$ & $83^{\circ} 12^{\prime}-83^{\circ} 38^{\prime}$ & $100-1229$ & 25,105 & 403 & 130522 & 24.8 & 1502.7 \\
\hline Kapilbastu & $27^{\circ} 25^{\prime}-27^{\circ} 48^{\prime}$ & $82^{\circ} 42^{\prime}-83^{\circ} 14^{\prime}$ & 93-1491 & 59,025 & 1,944 & 165,136 & 24.2 & $1,532.00$ \\
\hline Kailali & $28^{\circ} 22^{\prime}-29^{\circ} 05^{\prime}$ & $80^{\circ} 30^{\prime}-81^{\circ} 18^{\prime}$ & 109-1950 & 198,239 & 2,334 & 328,716 & 20.7 & $1,719.00$ \\
\hline Total & & & & 570,853 & 13087 & $1,197,262$ & & \\
\hline
\end{tabular}

Source: DOHM, 2017; DFRS, 2016

\section{SAMPLING METHOD}

The area of community plantation was 4.81 ha and that of private plantation was 5.57 ha. Both primary and secondary data were collected to meet the objectives (DoF, 2004). Total 215 sample plots were established having $20 \mathrm{~m} * 25 \mathrm{~m}$ in the field. So, diameter and height of 8644 plants were measured from the seven districts. Specifically, 97 and 118 samples were gathered from community and private plantations respectively. The diameter and height of trees were measured by and spacing between plants was also measured. The stratified random sampling was applied based on private and community plantation. A total of 102 soil samples from 0-10, 10-20 and 20-30 cm were collected. Collected data were analyzed. 
Mean of growth of diameter, height, basal area, volume, biomass and carbon using following formulae:

Mean Volume in $\mathrm{m}^{3}(\mathrm{MV})=$ Sum of total volume /total number of measured tree

Mean Annual Volume Increment (MAVI) = MV/Age of tree

Mean Biomass in $\mathrm{kg}(\mathrm{MB})=$ Sum of total biomass /total number of measured tree

Mean Annual Biomass Increment $(\mathrm{MABI})=\mathrm{MB} /$ Age of tree

Mean Carbon in $\mathrm{kg}(\mathrm{MC})=$ Sum of total Carbon /total number of measured tree

Mean Annual Carbon Increment $(\mathrm{MACI})=\mathrm{MC} / \mathrm{Age}$ of tree

Total Quantity /ha= Sum of Total Quantity/Actual Area of total sample plot sampled in ha

In addition, for Carbon content in the soil was analyzed by using dry combustion method (Walkley \& Black, 1958) Nitrogen was analyzed using Kjeldahl Method (Kjeldahl, 1883), Potassium, Ammonium Acetate Method for K Determination (Hanway and Heidel, 1952). In addition, Olsen's Method (Olsen et al., 1954) was applied for Phosphorus analysis and $\mathrm{pH}$ meter for $\mathrm{pH}$ analysis (Bates, 1954).

\section{RESULT AND DISCUSSION}

\subsection{Growth Performance of Tectona Grandis in Community and Private Plantation}

The age range of T. grandis was 3 to 50 years and 3 to 30 years in community and private plantation respectively. The mean volume and mean annual volume increment (MAVI) in community plantation were $171.46 \pm 11.6 \mathrm{~m}^{3} / \mathrm{ha}$ and $8.8 \mathrm{~m}^{3} / \mathrm{ha}$ whereas these values were $91.61 \pm 4.59 \mathrm{~m}^{3} / \mathrm{ha}$ and $10.2 \mathrm{~m}^{3} / \mathrm{ha}$ respectively in private plantation. Similarly the basal area (BA) was $17.85 \pm 1.00 \mathrm{~m}^{2} / \mathrm{ha}$ and $14.13 \pm 0.49$ $\mathrm{m}^{2} /$ ha with the mean above ground tree carbon (MAGTC) of $124.56 \pm 5.08$ ton and $40.2 \pm 2.0$ ton /ha and the average density of 604 and $1031 \mathrm{stem} / \mathrm{ha}$ in community and private plantation respectively (Table 3). The reason of higher growth in community plantation was due to low stem density per ha than private plantation, it was nearly 1.9 times more $(1031 \mathrm{stem} / \mathrm{ha})$. The higher the stem density the lower diameter increment (Thapa, and Gautam, 2007, FRA/DFRS, 2014). According to them, MDBH and MH in Shankharapur, Rupandehi, Nepal of 7.5 years of plantation before thinning were $11.7 \mathrm{~cm}$ and $12.4 \mathrm{~m}$ which was comparable with the 7 years MDBH and MH growth in this research.

According to Evans and Turnbull, (2004), the MAI in tropical forest plantation is $15-40 \mathrm{~m} / \mathrm{ha} / \mathrm{yr}$ and $1-7 \mathrm{~m}^{3} / \mathrm{ha} / \mathrm{yr}$ in natural tropical forest. The mean total yield from $T$. grandis plantations in Nilambar of India was $151.257 \mathrm{~m}^{3} / \mathrm{ha}$ and the MAI during the rotation of 53 years was $2.854 \mathrm{~m}^{3} / \mathrm{ha} / \mathrm{yr}$. The mean total yield and MAI for Kerala were $144.833 \mathrm{~m}^{3} / \mathrm{ha}$ and $2.287 \mathrm{~m} / \mathrm{ha} / \mathrm{yr}$ respectively in a mean rotation of 58 year (Chundamanni, 1997). Author Keogh (1996) stated that the aim of at least $8 \mathrm{~m}^{3} / \mathrm{ha} / \mathrm{yr}$ MAI is feasible for $T$. grandis plantation. Comparing with these results, the MAI in plantation of both community and private were greater $>8 \mathrm{~m} / \mathrm{ha} / \mathrm{yr}$, so the growth was found feasible for Nepal although this was much less than that of Keogh, 1996.

Table2. Mean Statistics For T. Grandis Plantation Forest Of Nepal

\begin{tabular}{|c|c|c|c|c|c|c|}
\hline Forest type & $\begin{array}{l}\text { Age } \\
\text { (Yr) }\end{array}$ & $\begin{array}{c}\text { Vol } \\
\left(\mathrm{m}^{3} / \mathrm{ha}\right) \pm \mathrm{SE}\end{array}$ & $\begin{array}{l}\text { MAVI } \\
\left(\mathbf{m}^{3} / \mathbf{h a}\right)\end{array}$ & $\begin{array}{c}\text { BA } \\
\left(\mathbf{m}^{2} / \mathbf{h a}\right) \pm \mathrm{SE}\end{array}$ & $\begin{array}{c}\text { MAGTC } \\
\text { (ton/ha) } \pm \text { SE }\end{array}$ & Density/ha \\
\hline Community & $3-50$ & $171.46 \pm 11.6$ & 8.8 & $17.85 \pm 1.00$ & $124.56 \pm 5.08$ & 604 \\
\hline Private & $3-32$ & $91.61 \pm 4.59$ & 10.2 & $14.13 \pm 0.49$ & $40.2 \pm 2.0$ & 1031 \\
\hline
\end{tabular}

\subsection{Soil Organic Carbon in Community and Private Plantation}

The average soil organic carbon from the surface of $0-30 \mathrm{~cm}$ layer of soil in community plantation of T. grandis was estimated to be $38.29 \pm 6.05$ ton/ha whereas in private plantation it was found to be $32.77 \pm 2.57 \mathrm{ton} / \mathrm{ha}$. The first $0-10 \mathrm{~cm}$ layer of soil had maximum soil carbon. However, there was no significant difference in SOC available amount in each layer of 1-10, 10-20 and 20-30 cm when compared at 5\% level of significance. In the community and private plantation of $T$. grandis, SOC was not significantly difference (Table 4). However, the district wise data showed that the availability in different district with community and private plantation land is different (Table 5). Soil carbon variation depends up on the microbial activities. The average SOC in Tarai forest of Nepal was 33.66 ton/ha (FRA/DFRS, 2014). In private $T$. grandis plantation, the average SOC was very near to Forest Research Assessment result of 32.77 ton /ha (FRA/DFRS, 2014). 
Table3. Soil Organic Carbon on T. grandis Plantation Forest

\begin{tabular}{|c|c|c|c|c|c|c|c|c|c|}
\hline \multirow{2}{*}{ Plantation } & \multirow{2}{*}{$\begin{array}{c}\text { Soil } \\
\text { depth } \\
\text { (cm) }\end{array}$} & \multicolumn{7}{|c|}{ Soil Organic Carbon in Districts (ton/ha) } & \multirow{2}{*}{$\begin{array}{c}\text { Total } \\
(\text { ton } / \text { ha } \pm \text { SE })\end{array}$} \\
\hline & & Jhapa & Rautahat & Chitwan & Nawalparasi & Rupandehi & Kapilbastu & Kailali & \\
\hline \multirow{3}{*}{ Community } & $0-10$ & 14.53 & 22.46 & 9.88 & 5.50 & 15.65 & 12.85 & 18.08 & $14.51 \pm 1.87$ \\
\hline & $10-20$ & 12.21 & 17.27 & 7.85 & 3.72 & 9.48 & 8.15 & 16.19 & $11.70 \pm 2.04$ \\
\hline & $20-30$ & 5.65 & 24.94 & 1.93 & 4.46 & 6.73 & 19.51 & 15.33 & $12.07 \pm 2.72$ \\
\hline & $0-30$ & 32.38 & 64.67 & 19.67 & 13.67 & 31.86 & 40.51 & 49.59 & $38.29 \pm 6.05$ \\
\hline \multirow{3}{*}{ Private } & $0-10$ & 12.68 & 14.54 & 14.59 & 6.26 & - & 14.57 & 17.24 & $12.80 \pm 1.06$ \\
\hline & $10-20$ & 12.37 & 11.85 & 8.41 & 5.50 & - & 11.30 & 15.05 & $9.96 \pm 1.22$ \\
\hline & $20-30$ & 8.22 & 10.88 & 18.10 & 7.75 & - & 7.87 & 10.57 & $10.29 \pm 1.20$ \\
\hline Total & $0-30$ & 33.26 & 37.28 & 41.10 & 19.51 & - & 33.74 & 42.85 & $32.77 \pm 2.57$ \\
\hline
\end{tabular}

\subsection{Soil N, P, K, Ph, BD and Texture in Private and Community Plantations}

The nutrients contents were varied in private and community plantation. Total nitrogen $0.07 \%$, phosphorus $21.23 \mathrm{Kg} / \mathrm{ha}$ and potassium $166.04 \mathrm{~kg} / \mathrm{ha}$. Similarly, in private plantation, carbon $0.84 \%$, total nitrogen $0.06 \%$, phosphorus $53.29 \mathrm{Kg} / \mathrm{ha}$ and potassium $171.55 \mathrm{~kg} / \mathrm{ha}$ was estimated. The $\mathrm{pH}$ value of soil from the first $30 \mathrm{~cm}$ layer was 6.50 for community plantation and 6.46 for private plantation. Bulk density (BD) for community and private plantation land soil were 1.44 and $1.40 \mathrm{gm}$ per $\mathrm{cm}^{3}$ respectively. Both of the forest land had moderately acidic soil of $\mathrm{pH} 6.50$ (community plantation) and 6.46 (private plantation). The texture of the soil was loam (L) to sandy loam (SL) in both plantation regimes (Table 6). Independent Sample mean t-test was applied to compare the soil nutrients. There was a significant difference in $\mathrm{P}$ in private and community plantation at $5 \%$ level of significance. However, there was no significance difference in other nutrient contents.

Liu, et al (2014), justified that SOC increased with the succession in 0-10 cm soil layer. The succession in community plantation is more when compared to private land. So, this argument may also be matched with the result. The sandy loam soil texture was recorded in T.grandis plantation forest in Uttarakhanda, India (Salim, et al., 2018) which is quite similar results with this study. Adkulne, (2011) found that $\mathrm{pH}$ of soil 5.77-8.33 in T.grandis plantation in Nigeria, This range was also similar in Nepal. According to Vitousek, et al (2010), six mechanisms can cause P limitation to terrestrial ecosystem: $\mathrm{P}$ depletion, soil barriers, transactional, low parent material, $\mathrm{P}$ sinks and anthropogenic forcing. According to Chamshama, et al., (2000). Jordon (1985) suggested that when the natural forest is cut and burnt, there is quick scarcity of $\mathrm{P}$ in tropical soils due to destruction of mechanism of $\mathrm{P}$ mobilization. In community plantation, there was natural forest before plantation. Also the fire risk was found higher in community plantation than private plantation. So, the available $P$ in community plantation can be lower.

Table4. Soil Parameters Status in Community and Private Plantation of T. Grandis

\begin{tabular}{|c|c|c|c|c|c|c|c|c|}
\hline SN & District & Plantation & N\% & P kg/ha & K kg/ha & pH & BD gm/cc & Tex. \\
\hline \multirow{2}{*}{1} & \multirow{2}{*}{ Jhapa } & Community & 0.07 & 33.55 & 208.00 & 6.24 & 1.12 & SL \\
\hline & & Private & 0.06 & 78.26 & 403.47 & 7.13 & 1.02 & $\mathrm{~L}$ \\
\hline \multirow{2}{*}{2} & \multirow{2}{*}{ Rautahat } & Community & 0.11 & 36.89 & 179.20 & 6.06 & 1.07 & SL \\
\hline & & Private & 0.06 & 27.70 & 198.60 & 5.72 & 1.12 & Sl \\
\hline \multirow{2}{*}{3} & \multirow{2}{*}{ Chitwan } & Community & 0.08 & 9.97 & 160.00 & 7.26 & 1.34 & $\mathrm{~L}$ \\
\hline & & Private & 0.05 & 78.57 & 80.80 & 5.76 & 1.42 & SL \\
\hline \multirow{2}{*}{4} & \multirow{2}{*}{ Nawalparasi } & Community & 0.05 & 8.70 & 103.60 & 6.49 & 1.51 & $\mathrm{~L}$ \\
\hline & & Private & 0.05 & 79.25 & 163.20 & 6.62 & 1.45 & $\mathrm{~L}$ \\
\hline \multirow{2}{*}{5} & \multirow{2}{*}{ Kapilbastu } & Community & 0.06 & 12.04 & 124.80 & 7.23 & 1.68 & $\mathrm{~L}$ \\
\hline & & Private & 0.06 & 13.15 & 83.60 & 6.91 & 1.63 & SL \\
\hline \multirow{2}{*}{6} & \multirow{2}{*}{ Kailali } & Community & 0.08 & 30.32 & 197.87 & 6.77 & 1.63 & SL \\
\hline & & Private & 0.06 & 42.80 & 99.60 & 6.65 & 1.75 & SL \\
\hline 7 & Rupandehi & Community & 0.05 & 17.10 & 188.80 & 5.42 & 1.72 & $\mathrm{~L}$ \\
\hline
\end{tabular}

\subsection{Correlation among Soil Parameters and Growth of T. Grandis}

The Pearson Correlation was applied to find the correlation with Nutrients level with growth performance of $T$. grandis. These correlations were also examined using ANOVA. The result showed that there was a positive correlation between nutrients parameters and growth performance. Specifically, R value of MABAI of $T$. grandis and carbon was low 0.49 was but its significant relation 
(p value $=0.00)$. According to Salim et al. $(2018)$, high BD means low organic matter (low soil nutrients) and vice-versa. The negative correlation between soil nutrients and BD may match with their findings. Adekunle, et al. (2011) reported that very high correlation $(+0.96)$ was found between $\mathrm{P}$ and growth variables in $T$. grandis plantation, Nigeria because of the importance of $\mathrm{P}$ in tree growth and development. Aydin et al.(2005) also reported that N and P will increase plant yield dry matter and nutrients. Similarly, soil $\mathrm{P}$ also showed a high positive correlation with growth variable except mean height. In this study, significant correlation of soil $\mathrm{P}$ with MADI $(\mathrm{r}=+0.455)$, MAHI $(\mathrm{r}=$ $+0.497)$ and density/ha $(\mathrm{r}=0.388)$ was recorded.

Table5. Correlation Test between Soil Parameters and Growth Parameters

\begin{tabular}{|c|c|c|c|c|c|c|}
\hline & & MADI & МАНI & MABAI & MAVI & Density/ha \\
\hline \multirow{3}{*}{$\mathbf{C}$} & Pearson Correlation & 0.01 & 0.14 & $-0.490^{* *}$ & $-0.462^{* * *}$ & $0.347^{*}$ \\
\hline & Sig. (2-tailed) & 0.95 & 0.42 & 0.00 & 0.01 & 0.04 \\
\hline & $\mathrm{N}$ & 34 & 34 & 34 & 34 & 34 \\
\hline \multirow{3}{*}{$\mathbf{N}$} & Pearson Correlation & -0.231 & -0.139 & $-0.400^{*}$ & -0.221 & 0.099 \\
\hline & Sig. (2-tailed) & 0.189 & 0.433 & 0.019 & 0.209 & 0.578 \\
\hline & $\mathrm{N}$ & 34 & 34 & 34 & 34 & 34 \\
\hline \multirow{3}{*}{$\mathbf{P}$} & Pearson Correlation & $0.455^{* *}$ & $0.497^{* *}$ & 0.088 & -0.167 & $0.388^{*}$ \\
\hline & Sig. (2-tailed) & 0.007 & 0.003 & 0.621 & 0.346 & 0.024 \\
\hline & $\mathrm{N}$ & 34 & 34 & 34 & 34 & 34 \\
\hline \multirow{3}{*}{$\mathbf{K}$} & Pearson Correlation & -0.035 & 0.080 & -0.199 & -0.143 & 0.100 \\
\hline & Sig. (2-tailed) & 0.846 & 0.653 & 0.260 & 0.418 & 0.574 \\
\hline & $\mathrm{N}$ & 34 & 34 & 34 & 34 & 34 \\
\hline \multirow{3}{*}{ pH } & Pearson Correlation & -0.25 & -0.14 & -0.27 & -0.11 & 0.14 \\
\hline & Sig. (2-tailed) & 0.16 & 0.42 & 0.12 & 0.52 & 0.44 \\
\hline & $\mathrm{N}$ & 34 & 34 & 34 & 34 & 34 \\
\hline \multirow{3}{*}{ BD } & Pearson Correlation & -0.097 & -0.125 & 0.120 & 0.196 & -0.230 \\
\hline & Sig. (2-tailed) & 0.59 & 0.48 & 0.50 & 0.27 & 0.19 \\
\hline & $\mathrm{N}$ & 34 & 34 & 34 & 34 & 34 \\
\hline
\end{tabular}

\subsection{Effect of Plantation Spacing Regime on Growth}

The results showed the variation in growth according to spacing between the plants. It was found that the highest MADI at $>3 \mathrm{~m}$ spacing with $1.33 \pm 0.028 \mathrm{~cm}$ but it was the lowest at $<2 \mathrm{~m}$ spacing with $1.17 \pm 0.018 \mathrm{~cm}$ (Table 10).

Table6. Mean Growth Parameters in Four Different Spacing of T. grandis Plantation

\begin{tabular}{|c|c|c|c|c|}
\hline Spacing & MADI $(\mathbf{c m}) \pm$ SE & MAHI $(\mathbf{m}) \pm$ SE & MABAI $\left(\mathbf{m}^{2}\right) \pm$ SE & MAVI $\left(\mathbf{m}^{3}\right) \pm$ SE \\
\hline $1(<2 \mathrm{~m})$ & $1.17 \pm 0.018$ & $0.923 \pm 0.009$ & $0.00161 \pm 4.863 \mathrm{E}-05$ & $0.01101 \pm 0.0004$ \\
\hline $2(2-2.49 \mathrm{~m})$ & $1.28 \pm 0.058$ & $0.863 \pm 0.029$ & $0.00184 \pm 1.507 \mathrm{E}-04$ & $0.01128 \pm 0.001$ \\
\hline $3(2.5-3 \mathrm{~m})$ & $1.30 \pm 0.029$ & $0.983 \pm 0.013$ & $0.00180 \pm 7.714 \mathrm{E}-04$ & $0.01181 \pm 0.001$ \\
\hline $4(4 \mathrm{~m})$ & $1.33 \pm 0.028$ & $1.105 \pm 0.015$ & $0.00185 \pm 4.201 \mathrm{E}-04$ & $0.01356 \pm 0.001$ \\
\hline
\end{tabular}

One wasy ANOVA was applied to compare the effect of spacing between plant to plant. It showed that there were significant difference between the MADI $(\mathrm{p}$ value $=0.002)$ and MAHI $(\mathrm{p}$ value $=$ 0.000 ) of the $<2 \mathrm{~m}, 2.50$ to $3 \mathrm{~m}$ and $4 \mathrm{~m}$ spacing at $5 \%$ level of significant. The Tukey's multiple comparisons showed difference in MADI and MAHI. Generally wider spacing indicates the good growth of $T$. grandis. It found that proper thinning and wide spacing produces large diameter trees (Ramnarine, et al. 2003, Kanninen et al., 2004, Zahabu et al. 2015). The result from Haninec, et al. (2016), showed that spacing $1 * 1 \mathrm{~m}$ created trees with lower growth parameters.

\section{CONCLUSION AND RECOMMENDATIONS}

The growth performance of $T$. grandis community plantation was better than private plantation in Nepal. Soil nutrients like $\mathrm{C}$ and $\mathrm{N}$ were found to be poor in both community and private plantation. However, availability of $\mathrm{K}$ was satisfactory. Soil nutrient $\mathrm{P}$, was showing significant correlation with diameter and height growth of tree in private plantation but poor in community plantation. This study showed that wider spacing of more than $2.5 \mathrm{~m}$ was found suitable for better growth in diameter and height of $\mathrm{T}$. grandis in Nepal. 
The study will be useful to find the appropriate rotation showing the highest increment. There should be an immediate application of thinning operation in the community and private $\mathrm{T}$. grandis plantation forest to make sufficient spacing for better growth of individual trees.

\section{REFERENCES}

[1] Adakunle, V.A.J., Alo, A.A., and Adekayode, F.O. (2011). Yields and Nutrient Pools in Soils Cultivated with T. grandis \& Gmelina arborea in Nigerian Rainforest Ecosystem. A Journal of the Saudi Society of Agricultural Sciences (2011) 10, 127-135.

[2] Amatya, S.M., Shrestha, K.R., (2016). Nepal Forestry Handbook.Nepal Foresters Association, Kathmandu- Nepal.

[3] Amatya, S.(2013). Financing for Sustainable Forest Management in Nepal. Indufor for intellengence.

[4] Amponsah, G. I., Meyer, W. L. and Murchison, H. G.(2000). Soil sampling size estimates for soils under teak (Tectona grandis Linn. F) Plantations and natural forests in Ashanti Region, Ghana. Can. J. Soil Sci. 80: $327-336$.

[5] Aydin, I., Uzun,F.(2005). N \& P fertilization of range lands affects yields, forage quality and botanical composition. European Journal of Agroforestry 23, 8-14.

[6] Ball, J.B. (1995). Development of Eucalyptus Plantations -an Overview. Proceedings of the Regional ExpertConsultation on Eucalyptus, Bangkok, Thailand 4-8 October 1993. Vol .I. pp.15-27.

[7] Bates, R. G., "Electrometric pH Determinations," Wiley, Yew York. 1954.

[8] CBS. (2011). National Population Census ( 2011): Household and Population by sex ward level. Central Bureau of Statistics, Thapathali, Kathmandu.

[9] Chundamanni, M. (1997). Teak Plantation in Kerala. An analysis of Productivity and Profitability. Thesis submitted in partial fulfilment of the requirements for the degree of DOCTOR OF PHILOSOPHY of the COCHIN UNIVERSITY OF SCIENCE AND TECHNOLOGY.

[10] DFO Chitwan.(2015). Annual Progress Report of Chitwan Forest Office on FY 2015/16 (Nepali version). District Forest Office Chitwan, Government of Nepal, Ministry of Forest and Soil Conservation.

[11] Chamshama, S. A. O. , Mugasha, A. G., Sanga, J. M., and Nshubemuki, L.(2000). Comparison of Some Chemical Properties of Soil under Teak and Natural Forests at Mtibwa, Morogoro, Tanzania. Journal of Tropical Forest Science 12(1):92-103.

[12] Charturvedi, A.N. \& Khanna, L.S., 1982.Forest Mensuration.International book Distributors 9/3 Rajpur Road, Dehra Dun - 248001.India.

[13] DFO Jhapa. (2015). Annual Bulletin on Ban dasakpragatipustika FY 2015/16 (Nepali version). District Forest Office Jhapa, Government of Nepal, Ministry of Forest and Soil Conservation.

[14] DFO Kapilvastu.(2015). Annual Bulletin on Improved Regeneration status in CFM Record in District Forest Office, Kapilvastu FY 2015/16 (Nepali version). District Forest Office Kapilvastu, Government of Nepal, Ministry of Forest and Soil Conservation.

[15] DFO Nawalparasi.(2015). Annual Bulletin on district programme of District forest office Nawalparasi FY 2015/16 (Nepali version). District Forest Office Nawalparasi, Government of Nepal, Ministry of Forest and Soil Conservation.

[16] DFO Rautahat.(2015). Annual Bulletin on Forest Area Record FY 2015/16 (Nepali version). District Forest Office Rautahat, Government of Nepal, Ministry of Forest and Soil Conservation.

[17] DFRS.(2015). District wise forest cover map of Nepal. Forest resource assessment (FRA) Nepal, Department of Forest Research and Survey (DFRS). Kathmandu, Nepal.

[18] DoF. (2004). Community Forestry Inventory Guideline.Department of Forests, Community Forestry Division, Nepal.

[19] DHM. (2017). Observed Climate Trend Analysis in the Districts and Physiographic Regions of Nepal (1971-2014). Department of Hydrology and Meteorology, Kathmandu.

[20] Evans, J. \& Turnbull, J.W. (2004). Plantation Forestry in the Tropics: Role of silviculture and use of planted forests for industrial, social, environmental and agroforestry purposes. 3rd edition. Oxford University Press, Oxford.

[21] FAO. (1993). Forest Resources Assessment 1990: Tropical Countries. FAO Forestry Paper (in press). Food and Agriculture Organization of the United Nations. Rome, 1993.

[22] FAO. (2016). Global Forest Resources Assessment 2015. How are the World's Forests Changing? Second Edition. Food and Agriculture Organization of the United Nations. Rome. Fernández-Moya, J., Alvarado , A., Mata, R., Thiele, H., Segura, J.M., Vaides, E., Miguel-Ayanz, A..S., and Marchamalo-Sacristán, M. (2015). Soil fertility characterisation of teak (Tectona grandis L.f.) plantations in Central America. CSIRO PUBLISHING. Soil Research, 2015, 53, 423-432 http://dx.doi.org/10.1071/SR14256. 
[23] Folster H, Khanna PK.(1997). Dynamics of nutrient supply in plantation soils. In: Management of soil, nutrients and water in tropical plantation forests (Nambiar EKS, Brown AG, eds). Australian Centre for International Agricultural Research, Australia. pp: 339-379.

[24] FRA/DFRS. (2014). Tarai Forests of Nepal (2010 - 2012). Babarmahal, Kathmandu: Forest Resource Assessment Nepal Project/Department of Forest Research and Survey.

[25] Haninec, Peter \& Madera, Peter \& Smola, Martin \& Habrova, Hana \& Šenfeldr, Martin \& Úradníček, Luboš \& Rajnoch, Milan \& Pavliš, Jindřich \& Cafourek, Josef \& Novosadova, Katerina \& Šmudla, Radek. (2017). Assessment of teak production characteristics using $1 \mathrm{~m}$ spacing in a plantation in Nicaragua. Bois et Forets des Tropiques. 330. 37-47. 10.19182/bft2016.330.a31317.

[26] James M. Roshetko, Dede Rohadi, Aulia Perdana, Gerhard Sabastian, Nunung Nuryartono, Agus A. Pramono, Nurin Widyani, Philip Manalu, Muhammad A. Fauzi, Purnomo Sumardamto \& Nuning Kusumowardhani (2013) T. grandis agroforestry systems for livelihood enhancement, industrial timber production, and environmental rehabilitation, Forests, Trees and Livelihoods, 22:4, 241-256, DOI: 10.1080/14728028. 2013.855150

[27] Jordan, C. F.(1985). Nutrient Cycling in Tropical Forest Ecosystems. John Wiley \& Sons Ltd. 190 pp

[28] Kanninen, M.,Perez, D., Montero, M. and Viquez, E. (2004). Intensity and the timing of the first thinning of T. grandis plantations in Costa-Rika: results of the thinning trials. Forest Ecology and Management 203 (2004) 89-99

[29] Kaosa-ard, A.(1995). Overview of problems in teak plantation establishment. Teak for the Future Proceedings of the Second Regional Seminar on Teak. FAO Regional Office for Asia \& the Pacific (RAP) Bankkok, Thailand.

[30] Miller A. D.(1969). Provisional yield tables for T. grandis in Trinidad. Government Printery, Trinidad/Tobago, $21 \mathrm{p}$.

[31] Laar, A.V., Akca, A.(2007). Forest Mensuration. Managing Forest Ecosystems 13. Springer, Dordrecht.

[32] Nepal Human Development Report (2014). Beyond Geography, Unlocking Human Potential Copyright (C) 2014. Published by Government of Nepal, National Planning Commission Singha Durbar, and Kathmandu. ISBN: 978-9937-8874-0-3

[33] GoN/MoFSC. (2011). Forest Carbon Stocks Measurement: Guidelines for Measuring Carbon Stocks in Community-Managed Forests. A Joint Publication by Government of Nepal, ANSAB, FECOFUN, ICIMOD and funded by NORAD, second edition in July 2011. ISBN: 978-9937-2-2612-7.

[34] GoN/MoFSC.(2014). Nepal Biodiversity Strategy and Action Plan: 2014-2020. Government of Nepal, Ministry of Forest and Soil Conservation, Kathmandu, Nepal.

[35] Hanway, J. and Heidel, H. (1952) Soil analysis methods as used in Iowa State College Soil Testing Laboratory, Iowa State College Agriculture Bulletine 57, 1-13.

[36] Horgan, T., Keane, M., McCarthy, R., Lally, M. and Thompson, D.(2003). A Guide to Forest Tree Species Selection and Silviculture in Ireland. Ed. O'Carroll, J. COFORD, Dublin.

[37] IUFRO, 2018. Utilization of Planted T. grandis . Publication Alert : T. grandis net Bulletine Volume 11 (1): 2018. International Union of Forest Research Organization. Downloaded from https://www.iufro.org/science/divisions/division5/50000/50600/50602/ publications/\#c20880. Accessed on 19: 20, 04/05/2018.

[38] Jackson, J.K. (1994). Mannual of Afforestation in Nepal. Kathmandu: Forest Research and Survey Centre. Second edition.

[39] Kaosa-ard, A. (1998). Overview of Problems in T. grandis Plantation Establishment. T. grandis for the Future- Proceedings of the Second Regional Seminar on T. grandis . RAP Publication: 1998. T. GRANDIS NET Publication: No. 1. 29 May - 3 June 1995, Yangon, Myanmar. FAO Regional Office for the Asia \& Pacific. Accessed from http://www.fao.org/docrep/005/AC773E/ac773e08.htm on 4/22/2018 at 8:50 a.m.

[40] Kayastha, B. P. (1974). Site suitability of trial plantations of Teak (Tectona grandis). Forestry (4), 4-7. Journal of the Institute of Forestry.

[41] Keogh, R. (1996). T. grandis 2000: A consortium support model for greatly increasing the contribution of quality tropical hardwood plantations to sustainable development IIED Forestry and LandUse Series No. 9, IIED and ATF.

[42] KFRI and ITTO. (2003). Quality Timber Products of T. grandis from Sustainable Forest Management.

[43] Kindermann, G., M. Obersteiner, B. Sohngen, J. Sathaye, K. Andrask, E. Rametsteiner, B. Schlamadinger, S. Wunder, and R. Beach. 2008. "Global cost estimates of reducing carbon emissions through avoided deforestation.” Proceedings of the National Academy of Science 105. pp 164-170. 
[44] Lintangah, w., Nicholas, K.J., Mojiol, A.R., Kodoh, J., and Abdullah, N. (2016). A Comparison of Growth Performance of Trees Species Planted to Restore the Degraded Area of Former Copper Mining in Mamut, Ranau, and Sabah. International Journal of Agriculture, Forestry and Plantation, Vol. 2 (February.) ISSN 2462-1757.

[45] Liu X, Meng W, Liang G, Li K, Xu W. (2014) Available Phosphorus in Forest Soil Increases with Soil Nitrogen but Not Total Phosphorus: Evidence from Subtropical Forests and a Pot Experiment. PLoS ONE 9(2): e88070. doi:10.1371/journal.pone.0088070

[46] Kjeldahl J. New Method for the Determination of Nitrogen. Chem. News 1883, 48 (1240), 101-102

[47] Kokutse A. D., Stokes A., Kokutse N. K., Kokou K. (2010). Which factors most influence heartwood distribution and radial growth in plantation teak? Annals of Forest Science, 67 (4): 1-10.

[48] Kumar, B.M.; Kumar, S.S., and Fisher,R.F. (1998). Intercropping T. grandis with Leucaena increases tree growth and modifies soil characteristics. 1998 Kluwer Academic Publishers. Printed in the Netherlands. Agroforestry Systems 42: 81-89, 1998.

[49] Maslekar, A. R. (1981). Forester's Companion (Indian Forestry Handbook). Jugal Kishore and Company, Dehradun.

[50] Moustakas, A., \& Evans, M. R. (2015). Effects of growth rate, size, and light availability on tree survival across life stages: a demographic analysis accounting for missing values and small sample sizes. BMC Ecology, 15, 6. http://doi.org/10.1186/s12898-015-0038-8

[51] Paudel, D., Khanal, D.R., \& Branney, P.(2011). Transparency in Nepal's Forestry Sector : A Baseline Assessment of Legal Indicators, Provisions and Practices. Livelihood and Forestry Programme.

[52] Mwangi, J.R.(2015). Volume and Biomass Estimation Model For T. grandis grown at Longuza Forest Plantation Tanzania. A Dissertation Submitted in Partial Fulfilment of the Requirements for the Degree of Master of Science in Forest Resources Assessment and Management of Sokoine. University of Agriculture. Morogoro, Tanzaniya.

[53] Nayak P. K., Senapati S. C., 1998. Evaluation of tree species under various plant geometry. Environment and Ecology, 16 (2): 382-384.

[54] Nunifu, K. T.(1997). The growth and yield of teak (Tectona grandis Linn F.) plantations in Northem Ghana 1 O1 pp. MScF Thesis, Faculty of Forestry, Lakehead University. Advisor: Dr. H. G. Murchison.

[55] Ojeda, G.(2017). Rotation and Thinning in Teak Plantations. Achieved on date 10/05/2018 at 8:58 pm from https://farmfolio.net/author/glenn-ojeda/ .

[56] Ola-Adams B. A. (1990). Influence of spacing on growth and yield of Tectona grandis Linn. f. (teak) and Terminalia superba Engl. \& Diels (Afara). Journal of Tropical Forest Science, 2 (3): 180-186

[57] Olsen, S. R., C. V. Cole, F. S. Watanabe and L. A. Dean. 1954. Estimation of Available Phosphorus in Soils by Extraction with Sodium Bicarbonate. U. S. Department of Agriculture Circular No. 939. Banderis, A. D., D. H. Barter and K. Anderson. Agricultural and Advisor.

[58] Pandey, D. (1992). Assessment of tropical forest plantation resource. Department of Forest Survey, Swedish University of Agricultural Sciences. $141 \mathrm{p}$.

[59] Paudel S. and Sah J.P. (2003), Physiochemical characteristics of soil in tropical sal (Shorea robusta Gaertn.) forests in eastern Nepal, Himalayan j.Sci, 1(2):107-110.

[60] Proceedings of the International Conference on Quality Timber Products of T. grandis from Sustainable Forest Management Peechi, India, 2-5 December 2003.

[61] Ramnararine, S.,and Jhilmit, S.(2003). Teak in Trinidad and Tobago. Quality Timber Product of Teak from sustainable Forest Management. pp 104-115. Kerala Forest Research Institute, Peechi 680653 , Kerala, India

[62] Robertson, R.M., and Reilly, D.F.( 2006). Performance of a 16-year-old stand of T. grandis (T. grandis L.F.) in the Darwin area in relation to that in other trials in the Northern Territory. Northern Territory Government, Department of Primary Industry, Fisheries and Mines GPO Box 3000 Darwin, Northern Territory 0801 Australia.

[63] Satheesan, T., Sivanathawerl, T., Sivachandran, S. and Phuspakumara, D.K.N.G.(2016). Distribution, Growth and Aboveground Biomass of Teak (Tectona grandis L.) Plantation in Mullaitivu District of Sri Lanka. International Journal of Scientific and Research Publications, Volume 6, Issue 3, March 2016. ISSN 2250-3153

[64] Silva, J.A. and Uchida, R. (2000). Plant Nutrient Management in Hawaii's Soils, Approaches for Tropical and Subtropical Agriculture. College of Tropical Agriculture and Human Resources, University of Hawaii at Manoa, (C2000 
[65] Thapa, H.B.,Gautam, S.K. (2007). Growth performance of Tectonagrandis in the western Tarai of Nepal.BankoJankari, 15(2), 6-12.

[66] Vitousek PM, Porder S, Houlton BZ, Chadwick OA. (2010) Terrestrial phosphorus limitation: mechanisms, implications, and nitrogen-phosphorus interactions. Ecological applications 20: 5-15.

[67] Walkley, A. J. \&Black, I.A. (1934).An examination of Degtjareff method for determining soil organic matter and a proposed modification of the chromic acid titration method. Soil Science 37: 29-38.

[68] Zahabu, E., Raphael, T., Chamshama, Iddi, S., and S.A.O. and Malimbwi, R.E. (2015). A Research Article on "Effect of Spacing Regimes on Growth, Yield, and Wood Properties of T. grandis at Longuza Forest Plantation, Tanzania". 2015. Hindawi Publishing Corporation International Journal of Forestry Research Volume 2015, Article ID 469760, 6 pages http://dx.doi.org/10.1155/2015/469760.

Citation: B.R. Pokhrel, R.A. Mandal" Assessing Growth Performance of Tectona Grandis in Nepal" International Journal of Advanced Research in Botany (IJARB), vol. 5,no.1, pp.25-33, 2019. http://dx.doi.org/ 10.20431/2455-4316.0501004

Copyright: (C) 2019 Authors. This is an open-access article distributed under the terms of the Creative Commons Attribution License, which permits unrestricted use, distribution, and reproduction in any medium, provided the original author and source are credited. 